\title{
The Effects of Pilonidal Sinus Morphology on Surgical Selection
}

\section{Pilonidal Sinüs Morfolojisinin Cerrahi Seçim Üzerindeki Etkileri}

\author{
(D) Alpen Yahya Gümüşoğlu1, (D) Süphan Ertürk² \\ lBakırköy Dr. Sadi Konuk Training and Research Hospital, Clinic of General Surgery Department, İstanbul, Turkey \\ ${ }^{2}$ istanbul University Cerrahpaşa Faculty of Medicine, Department of General Surgery Department, İstanbul, Turkey
}

\section{ABSTRACT}

Objective: In this study we aimed to reveal the morphological parameters which are taken into account when determining the surgical technique and to define an algorithm to determine the surgical procedure for future patients, based on the histopathological data of patients who underwent surgical treatment for pilonidal disease, retrospectively.

Methods: In this study histopathology reports of 594 patients who were operated by different surgeons between 2007 and 2011 at Istanbul University Cerrahpasa School of Medicine General Surgery Department were evaluated retrospectively. By evaluating the histopathology reports of patients retrospectively, we acquired data on specimen size, number and radius of orifice, size of excision material and surgical margin. Besides histopathological findings, we also researched the effects of patient age and gender on the surgical selection.

Results: The Limberg flap was the most preferred method with a ratio of $68.7 \%$. The Limberg flap region and surgical margin were significantly higher than the other three surgical groups $(p<0.05$ ). Unlike the limberg, karydakis and primary repair methods; patients undergoing marsupialization surgery are increasing every passing year ( $<<0.05)$. When all the surgical procedures are studied, the female/male ratio in karydakis and primary repair operations were significantly higher.

Conclusion: In this study, according to the pathological findings, it seems surgical selection for the treatment of pilonidal sinus by surgeons is based on patient gender, degree of disease, healing process, size of the resection material and surgeon's experience.

Keywords: Pilonidal sinus, limberg, karydakis, primary repair, marsupialization

ÖZ

Amaç: Biz bu çalıșmamızda, cerrahi tedavi uygulanan pilonidal sinüs tanılı hastalarımızın histo-patolojik verilerinden yola çıkarak, kliniğimizde seçilen cerrahi tekniğin belirlenmesinde göz önüne alınan morfolojik parametreleri retrospektif olarak ortaya çıkarmayı ve ileride uygulanacak olan cerrahi girișimlerin seçiminde kullanılabilir algoritmaların olușturulması için bir temel oluşturabilmeyi amaçladık.

Yöntemler: Bu çalıșmada, İstanbul Üniversitesi Cerrahpașa Tıp Fakültesi Genel Cerrahi Anabilim Dalı'nda 2007 ile 2011 yılları arasında pilonidal sinüs tanısı ile farklı cerrahlar tarafından opere edilen 594 hastanın histopatoloji raporları retrospektif olarak incelendi. Piyesin boyutu, orifis sayısı ve çapı, eksizyon materyalinin boyutu, cerrahi sınır (fistül ağzının en yakın cerrahi sınıra olan mesafesi) parametreleri elde edildi. Histo-patolojik verilerin yanı sıra, hastaların yaş ve cinsiyetlerinin operasyon seçimine etkisi de araştıııdı.

Bulgular: Limberg flebi ile onarım, \%68,7'lik oran ile en çok tercih edilen yöntem olarak belirlendi. Limberg grubunda fleb alanı ve cerrahi sınır diğer üç ameliyat grubundan anlamlı olarak yüksek bulunmuștur $(p<0,05)$. Marsupiyalizasyon yönteminin, limberg, karydakis ve primer tamir ameliyatlarına göre, her geçen yıl kendi içinde anlamlı düzeyde daha fazla tercih edildiği gözlenmiștir $(p<0,05)$. Tüm yöntemler incelendiğinde Karydakis ve primer tamir uygulanan kadınların erkek hastalara göre oranı, diğer iki yöntemdeki orandan anlamlı fazla bulunmuştur $(\mathrm{p}<0,001)$.

Sonuç: Patolojik verilerden yola çıkarak yaptığımız inceleme sonucunda cerrahların pilonidal sinüs tedavi yöntemi tercihinde hastanın cinsiyetine, hastalığın derecesine, iyileșme sürecine, uyguladıkları cerrahi yönteme alışkanlıklarına ve rezeksiyon materyalinin genişliğine göre karar verdikleri görülmektedir.

Anahtar Kelimeler: Pilonidal sinüs, limberg, karydakis, primer tamir, marsupiyalizasyon

Received/Geliș tarihi: 17.01.2019 | Accepted/Kabul tarihi: 27.01.2019

Address for Correspondence/Yazıșma Adresi: Alpen Yahya Gümüșoğlu, Bakırköy Dr. Sadi Konuk Training and Research Hospital, Clinic of General Surgery Department, İstanbul, Turkey

Phone/Telefon: +90 5353078391 E-mail/E-posta: alpenygumus@hotmail.com ORCID-ID: orcid.org/0000-0001-5378-9074

Citation/Atıf: Gümüșoğlu AY, Ertürk S. The Effects of Pilonidal Sinus Morphology on Surgical Selection Bakırköy Tıp Dergisi 2019;15:259-64 https://10.4274/BTDMJB. galenos.2019.20190117060657 


\section{INTRODUCTION}

Pilonidal sinus disease was first defined in the literature in 1833 by Herbert Mayo as sinus containing hair (1). Generally, it can be seen at all ages, but is most common in the second and third decades with incidence identified as $26 / 100.000$ (0.026) (2). It is reported to be two times more common in males compared to females (3). Pilonidal sinus disease is most commonly observed a mean of $5 \mathrm{~cm}$ from the anus in the inter-gluteal cleft, as sinus mouth or mouths along the midline $(4,5)$.

Debates related to acquired or congenital hypotheses for the etiopathogenesis have continued for years. All etiologic factors are not clear; however, some known risk factors include excessive hairiness, obesity, long duration of sitting, local irritation, family history and insufficient personal hygiene (6). Acquired theories are more accepted for the etiology currently due to support for this theory as the disease is not limited to only the sacrococcygeal region but may occur in other body regions, recurrent disease may occur in the same region in spite of sufficient resection and it is observed more often in certain professional groups (barbers' hands, drivers' sacrococcygeal region) (7). In addition to conservative approaches to treatment, a variety of surgical methods are used. Selection of treatment method considers many factors in addition to the spread of the lesions including the efficacy of the selected method, complications, recurrence rates, duration for return to normal life and cost.

\section{METHOD}

This study included 594 patients operated by different surgeons at İstanbul Universty Cerrahpaşa Faculty of Medicine, Department of General Surgery from 2007 to 2011 for pilonidal sinus.

Consent was obtained from all patients who participated in the study. This study was approved by the Istanbul University Cerrahpașa Faculty of Medicine Ethics Committee numbered 16066 and dated 5 June 2012. The histopathology reports of patients were retrospectively reviewed and the effects of pilonidal sinus morphology on chosen surgical technique were researched. With this aim, parameters such as size of excision material, number of orifices, sinus length, fistula mouth (orifice diameter) and surgical margins (shortest distance between fistula mouth and surgical margin) were obtained from histopathologic records. In addition to this data, whether there was an effect of patients' age and gender on selection of operation was researched. An attempt was made to correlate the obtained histopathologic data with the chosen surgical technique. The surgical procedures performed were grouped under the headings Limberg, marsupialization, Karydakis flap and primary repair methods. An attempt was made to correlate the obtained histopathologic data with the chosen surgical technique. Of the 594 patients investigated in our study, only 7 were cases treated with different methods from these 4 techniques and these were excluded from the study.

\section{Statistical Analysis}

Descriptive statistics of data used frequency, proportion, mean and standard deviation. The distribution of variables was checked with the Kolmogorov Smirnov test. The Kruskal-Wallis test was used to analyze two groups, with sub-analyses performed using the Mann-Whitney $U$ test. Analysis of proportional data used the Fischer test if fit chisquare test conditions were not present. Analyses used the SPSS 20.0 program.

\section{RESULTS}

Of 594 patients, $87.5 \%$ were male $(n=520)$ and $12.5 \%(n=74)$ were female. The mean age of male patients was 27.6 years, while the mean age of female patients was 25.8 years. When groups are investigated, there was no significant difference between the age distribution in the four groups ( $p>0.05)$. There was significant difference identified for gender distribution $(p<0.05)$. When all methods are investigated, more female patients had Karydakis and primary repair methods applied compared to males, which were significantly high compared to the other two methods $(p<0.001)$ (Table 1$)$.

The flap area in the Limberg group was significantly higher compared to the other three surgery groups $(p<0.05)$. The primary repair and Karydakis method had flap areas similar to each other and identified to be smaller compared to the other two groups (Table 2).

The orifice number in the marsupialization group was significantly higher than the other three surgery groups $(p<0.05)$. The orifice number in the Karydakis and primary repair groups were identified to be lowest (Table 3 ).

In the Limberg group the surgical margin was found to be significantly longer than the other three surgery groups 
$(p<0.05)$. The surgical margin in the marsupialization group was significantly closer than the other groups $(p<0.05)$ (Table 3).

The fistula mouth (orifice diameter) was significantly higher in the Limberg group compared to the Karydakis and primary repair group $(p<0.05)$ (Table 4$)$.

The sinus length in the Karydakis group was significantly lower compared to the other three surgery groups $(p<0.05)$ (Table 4).

In the Karydakis and Limberg groups using flaps, there were significant differences in the side chosen for the flap $(p<0.05)$. The left side was chosen more in the Karydakis group compared to the Limberg group at significant rates (Table 5).

Five-year analysis of 594 patients found that repair with the Limberg flap was the most chosen method with a rate of $68.7 \%$ (Tablo 6, Figure 1).

The marsupialization method was observed to be chosen more with each passing year at significant levels compared to Limberg, Karydakis and primary repair surgeries $(p<0.05)$ (Table 7).

Table 1: Age and gender distribution by groups

\begin{tabular}{|c|c|c|c|c|c|c|c|c|c|c|}
\hline & & \multicolumn{2}{|l|}{ Limberg } & \multicolumn{2}{|l|}{ Karydakis } & \multicolumn{2}{|c|}{ Marsupialization } & \multicolumn{3}{|c|}{ Primary repair } \\
\hline & & Mean \pm SD & n (\%) & Mean \pm SD & n (\%) & Mean \pm SD & n (\%) & Mean \pm SD & n (\%) & $\mathbf{p}$ \\
\hline Age & & $27.3 \pm 9.6$ & & $27.3 \pm 8.1$ & & $25.3 \pm 6.2$ & & $27.9 \pm 12.5$ & & 0.809 \\
\hline \multirow[t]{2}{*}{ Gender } & Male & 374 & 91.7 & 74 & 77.1 & 31 & 91.2 & 33 & 70.2 & 0.000 \\
\hline & Female & 34 & 8.3 & 22 & 22.9 & 3 & 8.8 & 17 & 29.8 & \\
\hline
\end{tabular}

Kruskal-Wallis / chi-square test, SD: Standart deviation

Table 2: Flap area according to groups

\begin{tabular}{lllll}
\hline & $\begin{array}{l}\text { Limberg } \\
\text { Mean } \pm \text { SD }\end{array}$ & Karydakis & Marsupialization & Primary repair \\
& Mean \pm SD & Mean \pm SD & Mean \pm SD & $13.7 \pm 9.9$ \\
\hline Flap area & $18.3 \pm 9.4$ & $13.9 \pm 8.3$ & $15.8 \pm 14,5$ & \\
\hline Kruskal-Wallis / Mann-whitney U test, SD: Standart deviation & & & \\
\hline
\end{tabular}

Table 3: Orificew number and surgical margin according to groups

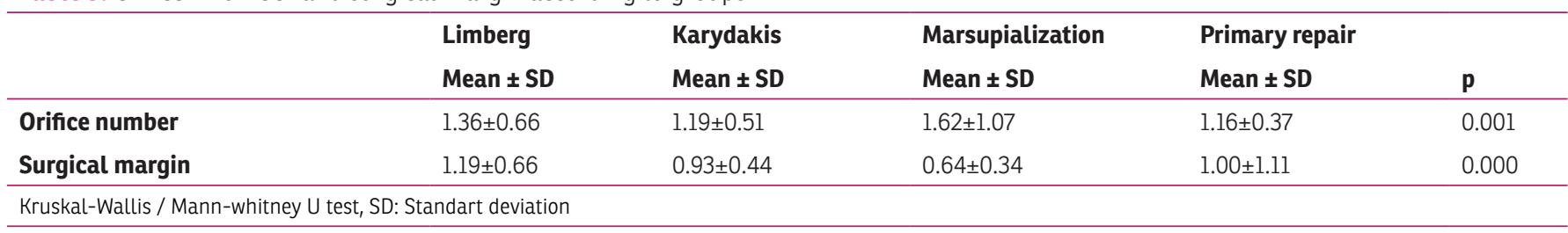

Table 4: Fistula mouth (orifice diameter) and sinus length according to groups

\begin{tabular}{lllll}
\hline & Limberg & Karydakis & Marsupialization & Primary repair \\
& Mean \pm SD & Mean \pm SD & Mean \pm SD & Mean \pm SD
\end{tabular}

Table 5: Flap side according two groups

\begin{tabular}{|c|c|c|c|c|c|c|}
\hline n (\%) & & $\begin{array}{l}\text { Limberg } \\
\text { n (\%) }\end{array}$ & $\begin{array}{l}\text { Karydakis } \\
\text { n (\%) }\end{array}$ & $\begin{array}{l}\text { Marsupialization } \\
\mathbf{n}(\%)\end{array}$ & $\begin{array}{l}\text { Primary repair } \\
\text { p }\end{array}$ & \\
\hline \multirow[t]{2}{*}{ Flap } & Right & $359 \pm 93.7$ & $9 \pm 69.2$ & - & - & 0.009 \\
\hline & Left & $24 \pm 6.3$ & $4 \pm 30.8$ & - & - & \\
\hline
\end{tabular}




\section{DISCUSSION}

There are many surgical methods defined for pilonidal sinus disease. We retrospectively investigated surgical methods applied by different surgeons for pilonidal sinus treatment by dividing patients into four groups. We aimed to research the efficacy of pilonidal sinus morphology on selection of surgical technique.

When the literature is investigated, pilonidal sinus disease is more commonly observed in males (8). In our study, we identified that $87.5 \%$ of patients undergoing surgery were male ( $n=520)$, while $12.5 \%$ were female $(n=74)$. In our study, the mean age for male patients was 27.6 years, while it was

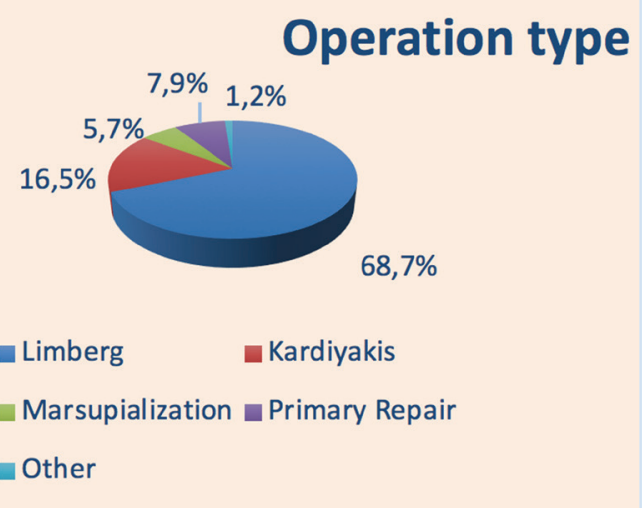

Figure 1: Number and ratio of operation type
25.8 years for females, in accordance with the literature (3). When surgeries included in our study are investigated, the most chosen method was Limberg flap (68.7\%). When Limberg series previously performed at our clinic and by Kapan et al. (9), Altınlı et al. (10) and Özgürtekin et al. (11) are investigated, factors like low recurrence and complication rates and lack of long-term care required in the period after surgery explain why the Limberg method is still the most commonly chosen approach in our clinic. Additionally, as stated in a study by lesalnieks et al. (12), the Limberg flap was identified to have superiority to primary repair in terms of wound separation and recurrence after surgery.

When all methods are investigated, the rates of Karydakis and primary repair applied to females compared to males was found to be significantly higher than the other two methods. Additionally, the specimen pieces removed with these methods were identified to be smaller compared

Table 6: Number and ratio of operation type

\begin{tabular}{llll}
\hline & & $\mathbf{n}$ & $\mathbf{\%}$ \\
\hline \multirow{3}{*}{ Operation type } & Limberg & 408 & 68.7 \\
& Karydakis & 98 & 16.5 \\
& Marsupialization & 34 & 5.7 \\
& Primary repair & 47 & 7.9 \\
& Other & 7 & 1.2 \\
\hline
\end{tabular}

Table 7: Distribution of operating rates over the years

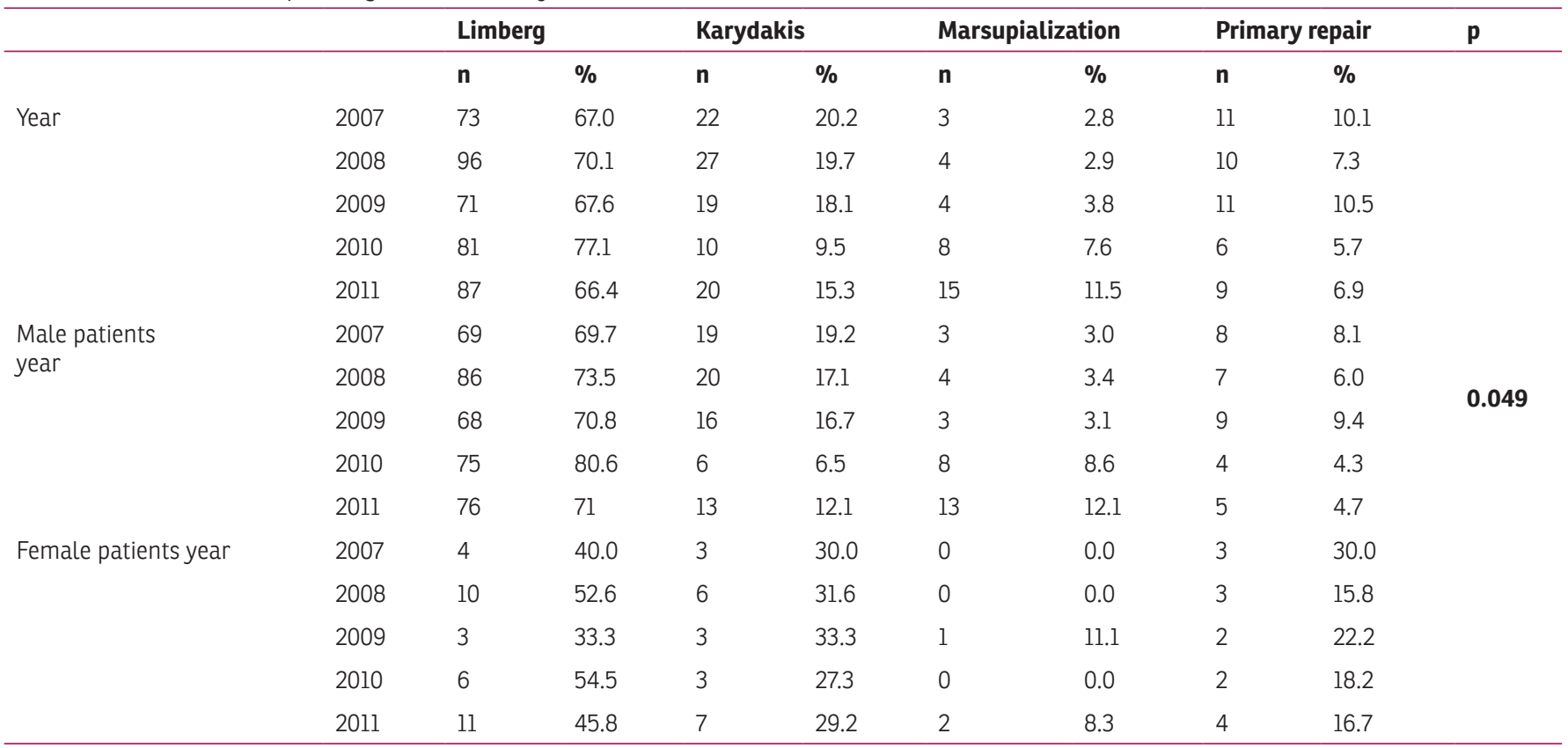


to other methods. We think the lower incidence of this disease due to the structural characteristics of females and females attaching more importance to cosmetics (less scar remaining and less deviation from natural appearance of the region in the postoperative period) caused this result. Erkent et al. (13) stated they chose the Karydakis and primary repair methods more often as they primarily considered cosmetic reasons.

The marsupialization method appears to be the method chosen least often in the study by Alver et al. (14) and in our study. The main reason for this is considered to be the long healing process, need for dressing and bad cosmetic outcomes. In a study by Yetişir et al. (15) comparing the outcomes of pilonidal sinus cases treated with marsupialization and Limberg methods, wound healing was quicker, postoperative flow and infection were observed less often, additionally return to normal activity was faster, there was less labor loss and higher patient satisfaction for patients with flap applied. As a result, they stated that broad-based Limberg flap method was a better treatment method compared to marsupialization.

When the area of specimens removed are investigated, the mean volume of specimens removed with the Limberg method was $18.3 \mathrm{~cm}^{3}$, and this was observed to be significantly larger compared to the other 3 methods. The excision areas for Karydakis and primary repair methods were $13.9 \mathrm{~cm}^{3}$ and $13.7 \mathrm{~cm}^{3}$, respectively, with smallest mean values. The study by Alver et al. (14) found the largest excision area was again in the Limberg group, with smallest excision area for primary repair. This study did not include the Karydakis method.

Orifice numbers were identified to be significantly higher in the group treated with marsupialization (mean 1.62). Harlak et al. (16) in a series including 587 patients calculated the mean orifice number as 2.71 based on physical examination findings.

When fistula mouth (orifice diameter) is investigated, the mean diameter in the Limberg method was $0.55 \mathrm{~cm}$, which was significantly larger compared to the other methods. The lowest value was identified as $0.41 \mathrm{~cm}$ in the primary repair group. The study by Alver et al. (14) identified the largest orifice diameter was in primary repair with mean $0.46 \mathrm{~cm}$. The sinus length was significantly longer in the marsupialization group compared to the other three groups (mean $2.23 \mathrm{~cm}$ ). In the study by Alver et al. (14), the marsupialization group had longest sinus length (mean $1.72 \mathrm{~cm})$.

Another variable we obtained from surgery reports is the side chosen for the flap. When the Limberg and Karydakis groups using flap methods are compared, in both groups though the flap was mainly turned from the right side, the rate of flaps turned from the left side was significantly higher using the Karydakis method compared to the Limberg method. As there is not information about the distribution of disease and the side where orifices are located in the surgery reports and pathologic data, factors affecting surgeon's choice about flap side are unknown.

\section{CONCLUSION}

Our study results show that the most commonly chosen method for surgical treatment of pilonidal sinus disease in our clinic was the Limberg flap method. When the specimen area is investigated, wider resection was chosen for cases with the Limberg method compared to the other three methods. An important factor in selection of this method is that it has been applied by Alver et al. (14) colleagues since 1988 in our clinic and has gained general acceptance based on outcomes.

In our study based on pathologic data, it appears that surgeons choose the method for treatment of pilonidal sinus based on patient gender, degree of disease, duration of healing, habits in surgical methods used and size of the resection material.

\section{Ethics}

Ethics Committee Approval: This study was approved by the Istanbul University Cerrahpaşa School of Medicine Ethics Committee numbered 16066 and dated 5 June 2012.

Informed Consent: Consent was obtained from all patients who participated in the study.

Peer-review: Externally peer-reviewed.

\section{Authorship Contributions}

Concept: A.Y.G., S.E., Design: A.Y.G., S.E., Data Collection or Processing: A.Y.G., Analysis or Interpretation: A.Y.G., S.E., Literature Search: A.Y.G., Writing: A.Y.G.

Conflict of Interest: No conflict of interest was declared by the authors. 
Financial Disclosure: The authors declared that this study received no financial support.

\section{REFERENCES}

1. Mayo $\mathrm{OH}$. Observations on injuries and disease of rectum. London: Burgess and Hill; 1833.p.45-6 (Quoted from:da Silva JH.Pilonidal cyct:cause and treatment. Dis Colon Rectum 2000;43:1146 -56.

2. Levinson T, Sela T, Chencinski S, Derazne E, Tzur D, Elad H, et al. Pilonidal Sinus Disease: A 10-Year Review Reveals Occupational Risk Factors and the Superiority of the Minimal Surgery Trephine Technique. Mil Med 2016;181:389-94.

3. Keighley MR. Pilonidal Sinus. In: Keighley MRB,Williams NS eds. Surgery of the Anus, Rectum \& Colon 2 WB Saunders Company, London 1999;539-63.

4. Ertürk S. Pilonidal Sinüs: Türkiye Klinikleri J Gen Surg-Special Topics 2010;3:75-83.

5. Alemdaroğlu K, Akçal T, Buğra D. Pilonidal Hastalık. Kolon Rektum ve Anal Bölge Hastalıkları 1. Baskı, İstanbul. 2003:185-96.

6. Aysan E, Ithan M, Bektas H, Kaya EA, Sam B, Buyukpinarbasili N, et al. Prevalence of sacrococcygeal pilonidal sinus as a silent disease. Surg Today 2013;43:1286-9.

7. Nivatvongs S, Gordon PH, Nivatvongs S. Principles and Practice of Surgery fort the Colon Rectum and Anus 3. Ed. Informa Healthcare USA Inc 2007;235-46.

8. Bradley L. Pilonidal sinus disease: a review. Part one. J Wound Care 2010;19:504-8.
9. Kapan M, Kapan S, Pekmezci S, Durgun V. Sacrococcygeal pilonidal sinus disease with Limberg flap repair. Tech Coloproctol 2002:6:27-32.

10. Altınlı E, Karahasanoğlu T, Hamzaoğlu ì. Kronik pilonidal sinüs tedavisinde geniş tabanlı Limberg flabi. Kolon Rektum Hastalıkları Dergisi 2002;12:97-100.

11. Özgürtekin R, Ersan Y, Özcan M, Özçelik F, Celik V, Cerçel A, et al. Therapy of pilonidal sinus with the Limberg transposition flap. Chirurg 1995;66:192-5.

12. Iesalnieks I, Ommer A, Petersen S, Doll D, Herold A. German national guideline on the management of pilonidal disease. Langenbecks Arch Surg 2016;401:599-609.

13. Erkent $M$, Şahiner iT, Bala M, Kendirci M, Yıldııım MB, Topçu R, et al. Comparison of Primary Midline Closure, Limberg Flap, and Karydakis Flap Techniques in Pilonidal Sinus Surgery.Med Sci Monit 2018;24:8959-63.

14. Alver 0 , Ertürk $S$, Yüceyar $S$, Gönenç $M$,Şen $B$, Karabulut $K$. Retrospective Analysis of Relations Between the Anatomopathologic Features of Specimens and Preferred Surgical Method in Sacrococcygeal Pilonidal Sinus Disease. ISUCRS 2006, XXI. Biennial Congress of International Society of the University of Colon and Rectal Surgeons, 25-28 June 2006, İstanbul-Türkiye. Abstract book, p:276.

15. Yetişir F, Kaya O,Baran I. Pilonidal sinüs tedavisinde marsüpializasyon ile Limberg flep yönteminin karșılaştırılması. Ulusal Cerrahi Dergisi 2005;21:184-90.

16. Harlak A, Menteș Ö, Özer M, Ersöz N, Coșkun A. Sakrokoksigeal Pilonidal Sinüslü 587 Hastanın Anamnez ve Fizik Muayene Bulgularının Değerlendirilmesi. EAJM 2006;38:103-6. 